Ar-Risalah: Media Keislaman, Pendidikan dan Hukum Islam

Volume XVIII Nomor 2 Tahun 2020

Print ISSN : 1693-0576

Online ISSN : 2540-7783

\title{
KENDALA PERUBAHAN STATUS BADAN KREDIT DESA MENJADI LEMBAGA KEUANGAN MIKRO DITINJAU DARI UNDANG-UNDANG NOMOR 6 TAHUN 2014 TENTANG DESA
}

\author{
A. Zaky Fuad ${ }^{1}$, Risma Nur Arifah ${ }^{2}$ \\ Universitas Islam Negeri (UIN) Maulana Malik Ibrahim Malang, Indonesia \\ e-mail : 1zakyfuad04@gmail.com, ${ }^{2}$ mrs reyzma@syariah.uin-malang.ac.id
}

\begin{abstract}
POJK Number 10/POJK.03/2016 about fulfilment rules Credit Bank of People and transformation, BKD to commit a process of Credit Bank of People explain that BKD (Village Credit Agency) an effort reinforcement institutions that have legal entities. In practice, this transformation is not easy, a recurring obstacle among others accordance asset ownership status. This research is study of empirical law with with a socilogical juridical approach, a concept approach, and a legislation approach. The results showed that the constraints of status changes that occurred in BUMDES in Genteng Subdistrict has several factors, including unclear regulations punlished by the government related to the mechanisms of transforming BKD into BUMDES, management of Human Resources (HR) which was not maximized, lack of response and support from the community. While efforts to resolve the status change constraints include the village government giving concrete understanding of the community related to changing the status of the BKD into BUMDES, uniting the vision and mission of the organizer, holding a discussion forum with several layers related and involved in the process of transferring status. While efforts to resolve constraint by Islamic law with holding a consensus deliberation for common wealth which in the end BKD in Banyuwangi Regency agreed to do cooperation between BUMDES which in this case BUMDES together trough PT. BKD Banyuwangi in order to save assets.
\end{abstract}

Keywords: Status Change Constraints, Village Credit Agency (BKD), BUMDES

\begin{tabular}{|c|c|c|}
\hline Accepted: & Reviewed: & Publised: \\
September 032020 & September 162020 & October 01 2020 \\
\hline
\end{tabular}

\section{A. Pendahuluan}

Perekonomian merupakan salah satu aspek yang memiliki pengaruh penting dalam kemajuan suatu badan usaha terutama dalam sistem yang berlaku dan berjalan didalamnya, sistem perekonomian yang baik pasti juga akan berdampak baik bagi para pihak yang bersangkutan. Secara hierarki sistem perekonomian yang berlaku di Indonesia, baik itu dari pemerintah pusat, pemerintah daerah bahkan sampai ke unit pemerintahan terkecil, yakni desa. Di sisi lain desa

This work is licensed under Creative Commons AttributionNon Commercial 4.0 International LicenseAvailable online on: http://ejournal.iaiibrahimy.ac.id/index.php/arrisalah/index 
sebabagai salah unit pemerintahan juga memiliki wewenang yang luas untuk mengelola usaha desa, baik jasa permodalan, simpan pinjam atau usaha, jasa atau usaha pelayanan publik serta usaha-usaha yang menguatkan usaha warga desa.

Badan Kredit Desa (BKD) merupakan salah satu lembaga yang keudukannya dipersamakan dengan bank, dengan alasan karena BKD memiliki fungsi dan potensi yang dominan dalam pengelolaan bidang keuangan, tidak dapat dipungkiri bahwa BKD memiliki peranan yang sangat penting dalam menunjang kemajuan pengembangan ekonomi skala desa, BKD telah membantu menopang kesejahteraan ekonomi masyarakat, sehingga keberadaan BKD di desa sangat sulit bahkan bisa dikatakan tidak dapat terpisahkan, selain dimana lembaga ini memang sudah berjalan dengan waktu yang lama, kepercayaan masyarakat desa lah yang menjadi faktor krusial di lembaga tersebut. karena kepercayaan merupakan aset terpenting yang harus dijaga oleh suatu lembaga keuangan, karena tanpa adanya kepercayaan dari masyarakat maka akan berimplikasi terhadap efisiensi suatu lembaga, sehingga dapat disimpukan bahwa konsep yang diberlakukan adalah memberikan kepercayaan, keadilan dan kelayakan bagi para nasabahnya.

Tantangan kedepan dalam hal perekonomian pedesaan yang berkelanjutan membutuhkan formulasi yang memposisikan peran pemerintah desa dan masyarakat menjadi satu kesatuan langkah yang sinergis dan bukan dikotomis. Untuk itu penting untuk melakukan penataan kelembagaan pembangunan perekonomian di desa.

Terbitnya Surat Keputusan Bersama (SKB) Menteri Keuangan, Menteri Dalam Negeri, Menteri Negara Koperasi dan Usaha Kecil Menengah, Gubernur Bank Indonesia tentang Strategi Pengembangan Lembaga Keuangan Mikro (LKM), SKB ini mengharuskan LKM termasuk didalamnya adalah BKD melakukan pengembangan melalui proses alih status ke dalam bentuk usaha yang telah memiliki kejelasan dasar hukumnya, yaitu : (i) Bank Perkreditan Rakyat; (ii) Koperasi, Badan Usaha Milik Desa (BUMDES) atau (iv) lembaga keuangan lainnya yang sesuai dengan peraturan perundang-undangan yang berlaku.

SKB ini juga menjelaskan tentang peran yang harus dilakukan oleh empat kementerian atau lembaga, yaitu : (a) Bank Indonesia memberikan konsultasi kepada LKM yang akan menjadi BPR sesuai dengan ketentuan yang berlaku dalam pendirian dan perizinan BPR, (b) Departemen Dalam Negeri, bersama-sama dengan Pemerintah Daerah melakukan pembinaan terhadap LKM yang akan menjadi BUMDES, (c) Kementerian Koperasi dan Usaha Kecil Menengah bersamasama dengan pemerintah daerah memfasilitasi, memberdayakan, dan membina LKM yang akan menjadi koperasi, (d) Departemen Keuangan memberikan konsultasi kepada LKM yang kegiatan usahanya menyerupai lembaga keuangan 
yang berada dalam pembinaan dan pengawasan Departemen Keuangan menjadi lembaga keuangan sesuai dengan ketentuan yang berlaku.

Pada tataran konsepsional, kehadiran SKB ini dimaksudkan untuk membantu LKM : (a) membentuk kejelasan status LKM yang belum berbadan hukum, (b) mengatur pengembangan LKM, (c) mengawasi pelaksanaan LKM dan mengembangkan potensi LKM (Nadapdap,2012). Namun pada tataran implementasinya tidak seindah yang diharapkan, bahkan di banyak tempat malah menimbulkan permasalahan baru, permasalahan ini muncul disebabkan oleh : (a) belum lahirnya aturan teknis terkait dengan SKB tersebut, (b) tumpang tindihnya tugas dari masing-masing lembaga kementerian, (c) lemahnya koordinasi sosialisasi SKB, (d) belum siapnya untuk menerima kebijakan transformasi (Djumhana, 2006).

Secara historikal BKD merupakan lembaga yang berada dalam kewenangan pengawasan langsung oleh Bank Indonesia (BI) yang mana BKD sendiri masih dalam tataran ekonomi tradisional desa, keberadaan BKD semakin terancam dengan adanya Peraturan Otoritas Jasa Keuangan (POJK) tentang pemenuhan ketentuan BPR dan transformasi BKD yang diberikan status sebagai Bank Perkreditan Rakyat (BPR). Implikasi diterbitkannya POJK ini terhadap BKD adalah bahwa BKD mau tidak mau harus mengubah status badan hukum usahanya yang awalnya belum berbadan hukum maka kedepannya harus berbadan hukum, maka saat ini BKD yang telah beroperasi selama puluhan tahun menjalankan fungsi inklusif di pedesaan harus memenuhi ketentuan sebagai BPR secara kelembagaan, prinsip kehati-hatian, pelaporan dan juga wajib menyampaikan rencana tindak (action plan) kepada OJK, jika BKD belum bisa mengakselerasikan diri sebagaimana BPR maka dapat memilih untuk mengubah kegiatan usaha menjadi LKM, BUMDES atau unit usaha BUMDES juga disertai dengan rencana tindak (action plan) nya, sementara dalam undang-undang desa mensyaratkan peralihan kepemilikan dan pengelolaan aset BKD lama tersebut mengikuti tata kelola pemerintahan desa.

Pengelolaan aset dalam BUMDES dikelola langsung oleh pegawai dan pengurus BUMDES melalui dana dari desa, sedangkan kepala desa berperan sebagai dewan pengawas, penasihat dan dewan komisaris yang bertgugas memeberikan nasihat kepada pelaksana operasional dalam pengelolaan BUMDES, mengendalikan pelaksanaan kegiatan BUMDES dan melindungi usaha desa terhadap hal-hal yang dapat menurunkan kinerja BUMDES.

Intervensi dari Peraturan Perundang-undangan dan Pemerintah menyebabkan keresahan di Masyarakat terutama masyarakat pedesaan yang masih awam akan adanya peraturan atas usaha yang telah mereka lakukan selama 
ini, karena mereka sudah menganggapnya sebagai tradisi yang memang orientasinya adalah untuk kesejahteraan masyarakat, juga kurang jelasnya regulasi yang diterbitkan oleh pemerintah mengenai mekanisme transformasi, sehingga banyak sekali kendala yang timbul dalam proses alih status melalui BKD menjadi Badan Usaha Milik Desa (BUMDES).

Kendala-kendala mulai bermunculan setelah diterbitkannya peraturan ini, banyak sekali cacat atau ketidakjelasan dalam peraturan yang telah diterbitkan oleh pemerintah, diantaranya adalah munculnya paradigma masyarakat terutama pengurus BKD yang tidak mau bersatu dengan desa dengan dalih bahwa merekalah yang membangun dan mengembangkan BKD tersebut tanpa ada partisipasi dari pihak desa. Muncul juga problem dalam pengelolaan aset yang awalnya diatur dan dikelola langsung oleh pihak BKD mau tidak mau harus diserahkan melalui desa, sehingga tidak sedikit masyarakat yang menolak ketika aset milik badan usahanya ini diambil alih oleh desa.

Aset BKD ini yang menjadi titik fokus, nasib aset yang ada dalam BKD ini setelah diterbitkannya regulasi-regulasi tentang BUMDES, maka dari ini diharapkan bahwa aset ini bisa diselamatkan sehingga tidak ada pihak yang dirugikan, yang mana pada nantinya hasil dari BUMDES ini agar memiliki manfaat dan kontribusi terhadap kesejahteraan masyarakat.

\section{B. Metode Penelitian}

Jenis penelitian yang digunakan adalah penelitian empiris, yaitu sebuah metode penelitian yang berupaya untuk meneliti bekerjanya hukum di masyarakat (Efendi \& Ibrahim, 2018) Maka, penulis terjun kelapangan guna untuk mengetahui terkait kendala perubahan status dari BKD menjadi LKM di BUMDES Kecamatan Genteng, diantaranya yaitu BUMDES "Lumbung Makmur" Desa Genteng Wetan, BUMDES "Lembu Suro" Desa Genteng Kulon dan BUMDES "Rukun Makmur". Penelitian ini menggunakan tiga jenis pendekatan, yaitu pendekatan yuridis sosiologis dengan mengkaji ketentuan hukum yang berlaku di masyarakat khususnya di BUMDES terkait kendala-kendala yang terjadi dalam proses alih status, pendekatan konsep dengan melakukan wawancara terkait dengan kendala perubahan status dan status kepemilikan aset pasca alih status dari BKD Menjadi BUMDES dan memadukannya dengan teori-teori dan konsep kepemilikan secara umum dan hukum Islam, dan pendekatan perundang-undangan dengan menelaah semua regulasi atau peraturan perundang-undangan yang berkaitan dengan objek penelitian. Sumber data dalam penelitian ini terdiri dari dua sumber yakni sumber data primer dan sekunder. Pertama, data primner dalam penelitian ini yaitu data yang diperoleh dari hasil penelitian yang dilakukan secara langsung di dalam 
masyarakat yang dalam hal ini adalah pengurus di masing-masing BUMDES. Kedua, data sekunder dalam penelitian ini yaitu data yang diperoleh dari hasil penelaahan kepustakaan dan literatur meliput tentang teori-teori kepemilikan, buku yang membahas tentang kepemilikan dan dokumen-dokumen resmi milik BUMDES. Metode pengumpulan data dalam penelitian ini adalah studi dokumentasi, observasi dan wawancara. Studi dokumentasi yang dimaksud peneliti adalah dengan melakukan studi terhadap sumber-sumber hukum baik primer maupun sekunder, observasi dilakukan dengan mengumpulkan data yang blangsung diambil saat terjun ke lapangan dan melakukan pengamatan dan pencatatan tentang informasi yang berkaitan dengan kendala perubahan status, wawancara yakni dengan melakukan tanya jawab secara langsungdengan menggunakan panduan daftar pertanyaan sesuai dengan data yang dibutuhkan oleh peneliti. Metode pengolahan data dalam penelitian ini dilakukan dengan cara memeriksa ulang mengenai jawaban dan informasi yang telah diperoleh peneliti. Selanjutnya melakukan editing yang bertujuan agar validitas dan kelengkapan data yang diperoleh lebih terjamin dan dapat dipertanggungjawabkan, kemudian data diklasifikasikan secara sistematis dan disesuaikan dengan permasalahan yang ada di dalam BUMDES, lalu kemudian data dianalisis secara deskriptif terkait dengan kendala perubahan status BKD menjadi LKM, hal ini dilakukan untuk memperoleh jawaban-jawaban atas permasalahan yang terjadi yanag pada akhirnya akan menjadi sebuah kesimpulan.

\section{Hasil dan Pembahasan}

\section{Kendala Perubahan Status Badan Kredit Desa Menjadi Lembaga Keuangan Mikro}

Badan Kredit Desa (BKD) merupakan salah satu lembaga yang kedudukannya dipersamakan dengan bank, dengan alasan karena BKD memiliki fungsi dan potensi yang dominan dalam pengelolaan bidang keuangan, tidak dapat dipungkiri bahwa BKD memiliki peranan yang sangat penting dalam menunjang kemajuan pengembangan ekonomi skala desa, BKD telah membantu menopang kesejahteraan ekonomi masyarakat, sehingga keberadaan BKD di desa sangat sulit bahkan bisa dikatakan tidak dapat terpisahkan, selain dimana lembaga ini memang sudah berjalan dengan waktu yang lama, kepercayaan masyarakat desa lah yang menjadi faktor krusial di lembaga tersebut. karena kepercayaan merupakan aset terpenting yang harus dijaga oleh suatu lembaga keuangan, karena tanpa adanya kepercayaan dari masyarakat maka akan berimplikasi terhadap efisiensi suatu lembaga, sehingga dapat disimpukan bahwa konsep yang diberlakukan adalah memberikan kepercayaan, keadilan dan kelayakan bagi para nasabahnya. 
Terbitnya Surat Keputusan Bersama (SKB) Menteri Keuangan, Menteri Dalam Negeri, Menteri Negara Koperasi dan Usaha Kecil Menengah, Gubernur Bank Indonesia tentang Strategi Pengembangan Lembaga Keuangan Mikro (LKM), SKB ini mengharuskan LKM termasuk didalamnya adalah BKD melakukan pengembangan melalui proses alih status ke dalam bentuk usaha yang telah memiliki kejelasan dasar hukumnya, yaitu : (i) Bank Perkreditan Rakyat; (ii) Koperasi, Badan Usaha Milik Desa (BUMDES) atau (iv) lembaga keuangan lainnya yang sesuai dengan peraturan perundang-undangan yang berlaku.

Secara historikal BKD merupakan lembaga yang berada dalam kewenangan pengawasan langsung oleh Bank Indonesia (BI) yang mana BKD sendiri masih dalam tataran ekonomi tradisional desa, keberadaan BKD semakin terancam dengan adanya Peraturan Otoritas Jasa Keuangan (POJK) tentang pemenuhan ketentuan BPR dan transformasi BKD yang diberikan status sebagai Bank Perkreditan Rakyat (BPR). Implikasi diterbitkannya POJK ini terhadap BKD adalah bahwa BKD mau tidak mau harus mengubah status badan hukum usahanya yang awalnya belum berbadan hukum maka kedepannya harus berbadan hukum, maka saat ini BKD yang telah beroperasi selama puluhan tahun menjalankan fungsi inklusif di pedesaan harus memenuhi ketentuan sebagai BPR secara kelembagaan, prinsip kehati-hatian, pelaporan dan juga wajib menyampaikan rencana tindak (action plan) kepada OJK, jika BKD belum bisa mengakselerasikan diri sebagaimana BPR maka dapat memilih untuk mengubah kegiatan usaha menjadi LKM, BUMDES atau unit usaha BUMDES juga disertai dengan rencana tindak (action plan) nya, sementara dalam undang-undang desa mensyaratkan peralihan kepemilikan dan pengelolaan aset BKD lama tersebut mengikuti tata kelola pemerintahan desa.

Pengelolaan aset dalam BUMDES dikelola langsung oleh pegawai dan pengurus BUMDES melalui dana dari desa, sedangkan kepala desa berperan sebagai dewan pengawas, penasihat dan dewan komisaris yang bertgugas memeberikan nasihat kepada pelaksana operasional dalam pengelolaan BUMDES, mengendalikan pelaksanaan kegiatan BUMDES dan melindungi usaha desa terhadap hal-hal yang dapat menurunkan kinerja BUMDES.

Intervensi dari Peraturan Perundang-undangan dan Pemerintah menyebabkan keresahan di Masyarakat terutama masyarakat pedesaan yang masih awam akan adanya peraturan atas usaha yang telah mereka lakukan selama ini, karena mereka sudah menganggapnya sebagai tradisi yang memang orientasinya adalah untuk kesejahteraan masyarakat, juga kurang jelasnya regulasi yang diterbitkan oleh pemerintah mengenai mekanisme transformasi, sehingga 
banyak sekali kendala yang timbul dalam proses alih status melalui BKD menjadi Badan Usaha Milik Desa (BUMDES).

Kendala-kendala mulai bermunculan setelah diterbitkannya peraturan ini, banyak sekali cacat atau ketidakjelasan dalam peraturan yang telah diterbitkan oleh pemerintah, diantaranya adalah munculnya paradigma masyarakat terutama pengurus BKD yang tidak mau bersatu dengan desa dengan dalih bahwa merekalah yang membangun dan mengembangkan BKD tersebut tanpa ada partisipasi dari pihak desa. Muncul juga problem dalam pengelolaan aset yang awalnya diatur dan dikelola langsung oleh pihak BKD mau tidak mau harus diserahkan melalui desa, sehingga tidak sedikit masyarakat yang menolak ketika aset milik badan usahanya ini diambil alih oleh desa.

BUMDES di Kecamatan Genteng memiliki tantangan masing-masing sesuai dengan kultur budaya masyarakatnya, seiring berjalannya BUMDES selama ini banyak sekali pro kontra yang terjadi baik dari pihak luar maupun dari pihak internal BUMDES sendiri, adanya miskomunikasi dan ketidakpahaman masyarakat mengenai sistematika dan regulasi BUMDES itu sendiri menjadi salah satu faktor yang menyebabkan timbulnya kendala-kendala dalam pelaksanaan operasional BUMDES maupun proses perubahan status BKD menjadi LKM. Kendala-kendala tersebut sebagaimana berikut : 1. Faktor Internal : (a) Adanya pegantian kepala desa, (b) Tidak adanya inisiator penggabungan BKD dengan BUMDES, (c) Kurang kompaknya pengurus, (d) Pengelolaan SDM yang belum maksimal, (e) Penolakan dari BKD, (f) Kurangnya pemahaman atas mekanisme transformasi. 2. Faktor Eksternal : (a) Adanya penolakan dari masyarakat desa, (b) Tidak adanya respon dan dukungan dari masyarakat, (c) Tidak adanya dukungan dari pemerintah, (d) Tidak jelasnya peraturan pemerintah, (e) Pola pikir yang keliru dari masyarakat.

Kepemilikan aset juga menjadi faktor yang paling diberatkan oleh pihak BKD karena mereka beranggapan bahwa ketika BKD beralih status menjadi LKM semua aset yang dimiliki oleh BKD secara tidak langsung akan berpindah kepimilikan ke pemerintah desa. Hak milik menurut ketentuan Pasal 570 Kitab Undang-Undang Hukum Perdata adalah hak dengan leluasa dan untuk berbuat bebeas terhadap kebendaaan itu dengan kedaulatan yang sepenuhnya, asal tidak bersalahan dengan undang-undang atau peraturan umum yang ditetapkan oleh suatu kekuasaan yang menetapkannya, dan tidak mengganggu hak-hak orang lain; kesemuanya itu dengan tak mengurangi kemungkinan akan pencabutan hak itu demi kepentingan umum berdasar atas ketentuan-ketentuan undang-undang dan dengan pembayaran ganti rugi.

Dengan dikuasainya suatu benda berdasarkan hak milik, maka seorang pemegang hak milik diberikan kewenangan untuk menguasainya secara tenteram 
dan untuk mempertahankannya terhadap siapapun yang bermaksud untuk mengganggu ketentramannya dalam menguasai, memanfaatkan serta mempergunakan benda tersebut, namun sehubungan dengan hal itu, Pasal 574 Kitab Undang-Undang Hukum Perdata menentukan bahwa : "tiap-tiap pemilik suatu kebendaan, berhak menuntut kepada siapapun juga yang menguasainya, akan pengembalian kebendaan itu dalam keadaan beradanya". Dalam Pasal selanjutnya, yakni Pasal 584 juga dijelaskan bahwa hak milik atas suatu benda tidak dapat diperoleh dengan cara lain, melainkan dengan pemilikan (pendakuan), karena perlekatan, karena daluwarsa, karena pewarisan, baik menurut undang-undang maupun menurut surat wasiat, dan dengan penunjukan atau penyerahan berdasarkan suatu peristiwa perdata untuk pemindahan hak milik, yang dilakukan oleh orang yang berhak untuk berbuat bebas terhadap barang itu (Muljadi \& Widjaja, 2003)

Asumsi bahwa seluruh kegiatan ekonomi mengambil tempat dalam kerangka kelembagaan dasar dari negara liberal (classical liberal statue). Asusmsi itu menyebutkan bahwa hak kepemilikan ditetapkan kepada individu menurut prinsip kepemilikan pribadi dan bahwa sanksi atas hak kepemilikan dapat dipindahkan melalui izin menurut prinsip kebebasan kontrak (freedom of contract). Melalui konsep dasar tersebut, hak kepemilikan atas suatu aset dapat dimengerti sebagai hak untuk menggunakan, untuk mengubah bentuk dan isi hak kepemilikan, dan untuk memindahkan seluruh hak-hak atas aset, atau beberapa hak yang diinginkan. Dengan deskripsi ini, hak kepemilikan hampir selalu berupa hak eksklusif, tetapi kepemilikan bukan berarti hak tanpa batas.

Bromley dan Cernea mendefinisikan hak kepemilikan sebagai hak untuk mendapatkan aliran laba yang hanya aman bila pihak-pihak yang lain respek dengan kondisi yang melindungi aliran laba tersebut. Dengan ini jelas bahwa sesungguhnya hak kepemilikan menyangkut penguasaan individu atas aset (dalam pengertian yang luas bisa berupa pengetahuan dan keterampilan) sehingga di dalam dirinya terdapat hak untuk menggunakan atau memindahkan atas tang aset dikuasai/dimiliki. Basis konsep ini yang nantinya bisa dipakai untuk memperluas cakupan dan pemahaman terhadap hak kepemilikan.

Kepemilikan dalam syariat Islam adalah penguasaan terhadap sesuatu sesuai dengan aturan hukum, dan memiliki wewenang untuk bertindak terhadap apa yang ia miliki selama berada dalam jalur dan koridor yang benar dan sesuai dengan hukum. Secara prinsip Islam tidak membatasi bentuk dan macam usaha bagi seseorang dalam memperoleh harta, begitupun juga tidak membatasi pula kadar banyak sedikit hasil yang dicapai oleh usaha seseorang. Hal ini tergantung kemampuan, kecakapan dan keterampilan masing-masing. 
Islam bersifat lebih memudahkan terutama dalam hal muamalah dalam konsepsi fiqh pembahasan muamalah merupakan pembahasan yang bersifat universal karenanya banyak sekali keringanan atau kemudahan yang ditawarkan oleh fiqh dalam bab muamalah.

Pengertian "kepemilikan" menurut istilah berbagai ungkapan yang dikemukakan oleh para ahli, namun secara esensial seluruh definisi itu pada prinsipnya sama. Misalnya Wahbah Zuhaily mendefinisikan al-milk sebagai berikut

$$
\text { إختصاص بالشيء يمنع الغير منه، و يمكن صاحبه من التصرف فيه ابتداء إلا لمانع شرعي. }
$$

"Pengkhususan atas suatu benda yang menghalangi orang lain bertindak atasnya dan memungkinkan pemiliknya melakukan tindakan secara langsung terhadap benda itu". (Zuhaily, 2006).

Sedangkan menurut Abi Al-Hasan Ali dalam kitabnya Al-Ta'rifat:

$$
\text { فيه فالشيء يكون مملوكا ولا يكون مرقوق. بين الإنسان و بين شيء يكون مطلقا لتصرفه فيه, و حاجزا عن تصرف غيره }
$$

"Hubungan yang sah secara syar'i yang terjadi antara manusia dan antara sesuatu secara mutlak untuk ditasharufkan, dan dapat dilakukan dalam pemanfaatan yang lain, dan sesuatu itu menjadi hak milik secara penuh bukan sebagian." (Al-Jurjany, 1971).

Menurut Wahbah Zuahily, kepemilikan dibagi menjadi dua macam, yaitu : (a) Al-Milk Al-tam (Kepemilikan yang Sempurna) adalah kepemilikan yang esensi benda dan manfaatnya dimiliki secara bersamaan, sekiranya tetap bagi pemilik seluruh hak-haknya secara syara', (b) Al-Milk Al-Naqish (Kepemilikan yang Kurang) adalah kepemilikan atas suatu benda saja, atau manfaatnya saja, kepemilikan ini dibagi menjadi tiga macam : (1) Kepemilikan atas benda saja, (b) Kepemilikan atas manfaat secara individu atau untuk mengambil manfaat, (c) Kepemilikan atas manfaat suatu benda (Zuhaily, 2006).

\section{Upaya dalam Menyelesaikan Kendala Perubahan Status Badan Kredit Desa Menurut dari Undang-Undang Nomor 6 Tahun 2014 tentang Desa}

Berangkat dari beberapa kendala yang muncul, pengurus-pengurus BUMDES dan perangkat desa mencoba membangun komunikasi supaya kedepannya BUMDES dapat terselamatkan dari kehilangan aset, berikut beberapa upaya dalam menyelesaikan kendala perubahan status BKD menjadi LKM, 
diantaranya : (a) Menyatukan visi dan misi pengurus, (b) melakukan forum dengan peguruan tinggi, (c) Memberikan penyadaran dan pemahaman kepada masyarakat, (d) Menyelamatkan dan mengembalikan aset BKD untuk modal usaha, (e) Menentukan bentuk badan hukum BUMDES. (f) Menyatukan BKD dengan penyertaan modal melalui desa, (g) Melakukan pelatihan softskill dan hardskill.

Bentuk badan hukum BKD saat ini sering dipertanyakan, karena dulu BKD merupakan bimbingan dari bank BRI yang waktu itu sebagai wakil dari Bank Indonesia. Menyikapi hal ini BUMDES Kabupaten Banyuwangi mengambil langkah tegas dalam hal pendirian badan hukum BUMDES, yakni dengan mendirikan BUMDES Bersama dari bentuk walnya yakni BKD. Perbincangan mengenai masalah BKD ini mulai ramai diperbincangkan bukan hanya di Kabupaten Banyuwangi saja namun di seluruh Indonesia, ketika di klaim bahwa BKD milik masyarakat akan tetapi tidak jelas sistem pengelolaan dan pertanggung jawabannya. Jika melihat pada peraturan yang diterbitkan oleh pemerintah maka pemerintah desa berhak untuk mengambil BKD sebagai aset milik Desa dan dikelola oleh BUMDES, akan tetapi banyak sekali penolakan dari pihak BKD sehingga terjadi tarik ulur kesepakatan yang sangat lama, sementara Desa bukan lembaga pengelola keuangan yang profit oriented sedangkan BKD murni profit oriented. Mendengar hal itu OJK langsung turun tangan untuk menangani permasalahan tersebut. sebagaimana pernyataan Bapak Hasan :

"Rata-rata BKD di seluruh Indonesia terutama di Banyuwangi ini, itu langsung ditarik menjadi asetnya BUMDES ndak mau, BKD nya ndak mau ketika langsung di klaim bahwa itu milik desa dan dikelola oleh BUMDES, nah di situ terjadi tarik ulur sampek lama, akhirnya karena disitu ada OJK, maka OJK turun saat itu mengundang seluruh Kepala Desa yang ada di Banyuwangi yang desanya ada BUMDES nya di Hotel AJM, maka disitulah di bentuk tim perumus, dan disitu ada 9 (sembilan) orang" (wawancara dengan Bapak Hasan, tanggal 09 Mei 2020).

Tim 9 tersebut terdiri dari 3 Unsur, yakni 3 orang dari Desa, 3 orang dari BKD dan 3 orang dari Kelurahan. Hal ini guna untuk menciptakan komunikasi yang baik antara masing-masing pihak, sehingga akhirnya seiring berjalannya waktu dan sering dilakukannya pertemuan-pertemuan dan diskusi-diskusi pada masingmasing desa sehingga akhirnya diambil kesepakatan bahwa BKD diberi 3 opsi, diantaranya : (1) BKD bisa beralih status menjadi Perseroan Terbatas (PT), (2) BKD bisa beralih status menajdi Bank Perkreditan Rakyat (BPR), (3) BKD bisa beralih status menjadi Lembaga Keuangan Mikro (LKM).

Akhirnya dari ketiga opsi tersebut diperoleh kesepakatan bahwa karena BKD sudah menjadi aset milik desa, maka seluruh BKD atau BUMDES yang ada di Kabupaten Banyuwangi bersepakat untuk bekerja sama sehingga menjadi PT. 
BKD Kabupaten Banyuwangi, yang mana nantinya akan dikelola oleh BUMDES. Kerja sama yang dilakukan bertujuan agar tidak timbul perpecahan BKD sebab adanya pergesekan antara pihak BKD dengan pihak Desa.

Tatanan dan model pengelolaan pada PT. BKD Kabupaten Banyuwangi ini, dikarenakan BKD merupakan unit usaha yang profit oriented maka berapa kekayaan atau aset yang dimiliki BKD di setiap desa baik berupa hutang-piutang, harta bergerak maupun tidak bergerak itu diakumulasikan yang nantinya akan menjadi saham bagi masing-masing BKD atau BUMDES itu sendiri.

Seiringan dengan hal itu, banyak konflik yang terjadi terutama konflik antara pemerintah desa dengan pengurus BKD. Akhirnya pemerintah mengambil jalan tengah yakni dengan melakukan penyertaan modal melalui desa, Penyertaan modal merupakan salah satu upaya pemerintah untuk menyelesaikan konflik yang terjadi antara pemerintah desa dengan masyarakat secara khusus yakni BKD, hal ini merupakan implikasi dari diterbitkannya peraturan pemerintah terkait transformasi BKD, hal ini sebagaimana disampaikan oleh Pak Hasan:

"jadi untuk menyelesaikan konflik atau penolakan yang terjadi maka pemerintah desa mengambikl jalan tengah yakni dengan mengembalikan aset BKD menjadi modal penyertaan" (wawancara dengan Bapak Hasan, tanggal 09 Mei 2020).

Hal ini sesuai dengan teori agensi atau teori keagenan yang menjelaskan tentang pemisahan antara fungsi pengelolaan dan fungsi kepemilikan dalam suatu perusahaan (Wangso, 2012). Dalam artian dalam hal kepemilikan aset nantinya akan tetap dikembalikan dalam bentuk modal usaha yang dikelola melalui BUMDES.

Upaya-upaya tersebut dilakukan untuk menyelamatkan semua pihak baik pengurus BKD, Pemerintah Desa maupun nasabah, sehingga nantinya tidak ada pihak yang merasa dirugikan. Sebagiamna disampaikan Ibu Emy Hidayati selaku informan yang juga termasuk aktivis BUMDES :

"Dadi ngeten (jadi begini) mas, karena saya selaku pihak dari kampus dan dulunya memang menggeluti hal ini, maka saya menginisiasi agar perguruangperguruan tinggi yang ada di Banuwangi ini untuk ikut turun membantu keresahan dan kebingungan masyarakat dalam hal proses alih status BKD, dengan apa?, dengan merancang forum-forum diskusi dengan pemerintah daerah sebagai fasilitator dalam kerja sama desa, lalau BPD sebagai penyelenggara permusyawaratan desa dan BKD selaku pengelola masa transisi" (wawancara dengan Ibu Emy Hidayati, tanggal 09 Januari 2020).

Melalui hasil musyawarah antar desa dan beberapa pihak terkait dalam masa transisi BKD juga merupakan solusi dari permasalahan ini, untuk 
memperoleh jawaban yang kongkrit terkait implementasi kebijakan yang tepat, dan tidak kebingungan ketika ditanya oleh masyarakat.

Ketidakpahaman masyarakat terutama pihak BKD memerlukan penjelasan dari pihak-pihak yang memang paham dan mengetahui proses transformasi mulai awal. Hal ini sebagaimana disampaikan oleh Bapak Hasan:

"Penolakan yang terjadi mengharuskan saya melakukan komunikasi kepada pihak BKD, dan memberikan jaminan tetap adanya pekerjaan bagi pengurus BKD, karena ini mas hal yang paling ditakutkan oleh pihak BKD ketika memang mereka harus berlalih status menjadi BUMDES" (wawancara dengan Bapak Hasan, tanggal 09 Mei 2020).

Esensi dalam proses komunikasi ini adalah untuk memperoleh kesamaan makna dan tujuan, agar dapat mensudahi konflik yang telah berlalu, dan bagaimana kedepannya saling bekerja sama untuk meraih kesuksesan BUMDES dengan memberdayakan masyarakat yang berorientasikan untuk mensejahterakan masyarakat desa.

Hal ini juga merupakan langkah sosialisasi kepada masyarakat dan memeberikan perlindungan hukum, yang dalam hal ini perguruan tinggi sebagai pendamping. Sosialisasi ini bertujuan untuk memberikan pemahaman terhadap masayarakat desa untuk memahami apa itu BUMDES, tujuan pendirian BUMDES, dan manfaat pendirian BUMDES.

Forum diskusi ini menjadi ajang musyawarah untuk membentuk perlindungan hukum preventif, yaitu perlindungan hukum yang bertujuan untuk mencegah terjadinya suatu sengketa (M. Hadjon, 1987). Sedangkan pelaksanaan proses alih status yang dilakukan sengan musyawarah mufakat menunjukkan bahwa pelaksanaan tersebut memberikan perlindungan hukum represif yaitu perlindungan hukum yang bertujuan untuk menyelesaikan suatu sengketa (M. Hadjon, 1987).

\section{Kesimpulan}

Berdasarkan analisis yang telah penulis paparkan, maka kesimpulan pada penelitian ini adalah Kendala perubahan status BKD menjadi LKM di BUMDES Kecamatan Genteng Kabupaten Banyuwangi terjadi karena adanya beberapa faktor penyebab terjadinya kendala yang terbagi menjadi dua, yaitu faktor internal dan faktor eksternal. Faktor internal kendala perubahan status yaitu adanya pergantian kepala desa, tidak adanya inisiator penggabungan BKD dengan BUMDES, kurang kompaknya pengurus, pengelolaan SDM yang belum maksimal, Penolakan dari BKD, kurangnya pemahaman masyarakat atas mekanisme trasnformasi. Sedangkan faktor eksternalnya, yaitu adanya penolakan dari 
masyarakat desa, tidak adanya respon dan dukungan dari pemerintah daerah, tidak jelasnya peraturan pemerintah, pola pikir yang keliru dari masyarakat.

Upaya penyelesaian kendala perubahan status di BUMDES Kecamatan Genteng Wetan Kabupaten Banyuwangi yaitu, menyatukan visi dan misi pengurus, melakukan forum dengan perguruan tinggi, memberikan penyadaran dan pemahaman kepada masyarakat, menyelamatkan dan mengembalikan aset BKD untuk modal usaha, menentukan badan hukum BUMDES, menyatukan BKD dengan penyertaan modal melalui desa, melaksanakan pelatihan softskill dan hardskill. Pada akhirnya untuk melakukan penyelamatan aset BKD se-Kabupaten Banyuwangi bersepakat untuk menyatukan aset melalui BUMDES dari masingmasing desa dengan melakukan kerjasama antar BUMDES yang dalam hal ini adalah BUMDES Bersama.

\section{Daftar Rujukan}

\section{Buku-Buku :}

Al-Jurjany, Abi Hasan Ali Bin Muhammad Bin Ali Al-Husainy. (1971). At-Ta'rifat, Beirut : Dar Al-Kotob Al-Ilmiyah.

Djumhana, Muhamad, Hukum Perbankan di Indonesia. (2006). Bandung: PT Citra Aditya Bakti.

Efendi, Jonaedi, dan Johnny Ibrahim. (2018). Metode Penelitian Hukum Normatif dan Empiris, Jakarta: Kencana.

M. Hadjon, Philipus. (1987). Perlindungan Bagi Rakyat indonesia, Surabaya : PT. Bina Ilmu.

Muljadi, Kartini dan Gunawan Widjaja. (2003). Seri Hukum Harta : Kekayaan Kebendaan pada Umumnya. Jakarta: Kencana.

Permata Aksara.

Nadapdap, Binoto. (2012). Hukum Perseroan Terbatas. Jakarta:

Zuhaily, Wahbah. (2006) Al-Fiqh Al-Islamy Wa Adillatuhu. Juz 6. Damaskus : Dar AlFikr.

\section{Peundang-Undangaan :}

Keputusan Bersama Manteri Keuangan, Menteri Dalam Negeri, Menteri Negara Koperasi dan Usaha Kecil Menengah dan Gubernur Bank Indonesia , Nomor : 351.1/KMK.010/2009, Nomor : 900-639A/2009, Nomor : 01/SKB/M.KUKM/IX/2009, dan Nomor : 11/43A/KEP.GBI/2009 tentang Strategi Pengembangan Lembaga Keuangan Mikro. 
A. Zaky Fuad \& Risma Nur Afifah

Peraturan Otoritas Jasa Keuangan (POJK) Nomor 10 Tahun 2016 tentang Pemenuhan Ketentuan Bank Perkreditan Rakyat dan Transformasi Badan Kredit Desa yang Diberikan Status Sebagai Bank Perkreditan Rakyat.

Undang-Undang Nomor 6 Tahun 2014 tentang Desa.

\section{Skripsi/Jurnal :}

Akbar, Ali. "Konsep Kepemilikan dalam Islam", Jurnal Ushuluddin, no.2, (2012) https://www.academia.edu/22157557/Konsep Kepemilikan dalam Islam

Wangso, Amanda. "Pengaruh Kebijakan Deviden, Struktur Kepemilikan, dan Kebijakan Hutang Terhadap Nilai Perusahaan dalam Prespektif Teori Agensi dan Teori Signaling" Journal Ilmiah Mahasiswa Manajemen, no.5(2012):1-6 http://journal.wima.ac.id/index.php/JUMMA/article/view/192 